\title{
Emotions in Intercultural Relations
}

\author{
Barbara Keys
}

A remarkable yet mostly overlooked feature of Akira Iriye's 1967 masterpiece, Across the Pacific: An Inner History of American-East Asian Relations, is its implicit argument that emotions play a crucial role in international relations. As Iriye later described it, the book reflected his view that international relations could not be fully understood without delving into "the intellectual, emotional, and psychological sources" that policymakers and the public drew on in forming ideas and opinions, which in turn influenced decision-making. ${ }^{1}$ Even as this approach became widely influential in diplomatic and international history, however, explicit attention to emotions as an analytical tool seemed to drop out of the picture. Iriye's attention to the role of mental images in shaping foreign policy and public opinion gave rise to a thriving subfield, and international historians became increasingly interested in the intangible elements of foreign relations, such as ideas, ideology, perceptions and misperceptions, and cultural interchange. Yet historians rarely focused on the emotions that underpinned these intangibles.

Meanwhile, traditionalists who focused on state-to-state relations and national security issues dismissed the cultural approach to international history as irrelevant or unimportant. The field of diplomatic and international history split into two camps: those who thought that culture mattered, and those who were sure that it did not. Though the culture camp has registered impressive growth in numbers and influence, the culture-versus-power divide continues to be one of the most contentious issues in the field. The study of emotion, which is now exciting great interest among historians, offers one possible route to bridge this long divide. Because emotions underlie both power and culture, they create links between the two forms of international relations. Indeed, emotions are not merely constitutive elements of each but are lines of transmission between the two. To study emotion is to study culture and power simultaneously.

A close examination of Across the Pacific shows how tightly culture and power are bound together by emotion. Iriye would later move away from this approach, arguing that culture, economics, and power were best treated 


\section{PROOF}

as distinct domains, to be analyzed separately. ${ }^{2}$ He became less interested in foreign policymakers than in societies as a whole and the "ideas, emotions, moods, religious trends, gender relations, and the like that constitute the makeup of a society as it interacts with other societies." In the 1990s he called for a new conceptualization of international relations as a "social context for interchanges among individuals and groups across national boundaries" in order to deal with "the roles played by ideas, aspirations, and emotions in the world." ${ }^{3}$ Emotions remained important to his analysis, but were now limited to the cultural domain. His early magnum opus, however, was an account of power as much as culture. It treated the two as interlinked-and undergirded by emotion. In explaining the vicissitudes of U.S.-Chinese-Japanese relations from the 18th to the 20th centuries, Iriye refers to fear, anxiety, hysteria, hope, regret, affection, desperation, excitement, sympathy, revulsion, and even love. More so than his later work, the book pays homage to emotions as constitutive of worldviews and attitudes that shaped crucial decisions of war and peace.

In summative accounts of his argument, Iriye presents the view that emotions predominated in international relationships when accurate information and clear-headed assessments were lacking, as they so often seemed to be in U.S.-East Asian relations, especially before World War II. Emotions, in this view, generally work as a negative or distorting influence on foreign relations; they are the unsophisticated antithesis of intellectualism. U.S.East Asian relations have too often been shaped by oversimplification and emotionalism, he explains in the preface. "Policies have been made on the basis of considerations tangential to the Pacific, mutual images have been formed with little basis in fact, and wars have been fought even though policies and images have not postulated wars." His book pleads for a less emotional, more intellectual understanding. His aim, he writes, is to bring "an intellectual analysis to a situation hitherto almost devoid of it," for "emotion, prejudice, and sentimental theorizing" have too often predominated in shaping U.S.-East Asian relationships. The book ends with an appeal to cultivate "genuine intellectual communication" instead of "propaganda, emotionalism, and excessive empiricism"; only then, he writes, "will it be possible to transcend the past and look toward a more peaceful Pacific." ${ }^{4}$

To be sure, the book had ample fodder to show that emotions had often inhibited rather than enhanced genuine understanding. For over a century, for example, Americans were enthralled by the mirage of a vast China market. Evidence that such dreams were unrealistic did not lead to reassessment; rather, the result was the reverse: the more hope was deferred, the more hope for future bonanzas seemed to grow. ${ }^{5}$ Such a reaction, so resolutely contradicting the available evidence, seems explicable only as the result of an emotional attachment in which the object of desire became more desirable the further it receded from reach. Similarly, Japanese-American relations in the last decades of the 19th century were characterized by a sense 


\section{PROOF}

\section{Barbara Keys}

of friendship and goodwill, Iriye argues, but it was based on misperceptions and lack of understanding, rather than sensible appraisals of common interests. On the American side, for example, emotionally based wishful thinking about Japan's Westernizing drive deeply colored perceptions of the country. ${ }^{6}$ As a corollary of Iriye's preference for sound appraisals, even profoundly hostile relations could be regarded as relatively positive if they were based on realistic, intellectually credible judgments. He argues, for example, that the Chinese Revolution of 1949 put Sino-American relations on a more sophisticated footing than had prevailed before, substituting "cool appraisals" of power considerations for the "romantic images, distortions, wishful thinking, irrelevant generalizations, and logical inconsistencies" that had guided earlier relations. Despite the dangers of Cold War hostility, Iriye wrote in 1967, Sino-American tensions were more likely than ever before to produce realistic assessments and "a saner approach to Asian problems." 7

Despite these arguments for de-sentimentalizing U.S.-East Asian relations, Iriye's approach to studying the interactions between emotionally inflected images and "cool appraisals" of power continually underlined the inseparability of the two. On one hand, the book yoked emotions and realistic appraisals of information in opposition to each other, charting a history in which emotion prevailed when information was lacking, whereas increased contact and deeper knowledge produced more realistic opinions and decision-making. ${ }^{8}$ On the other hand, however, throughout his analysis Iriye treats emotions as necessary to human thought. His account assumes that sentiment would never disappear and that feelings and perceptions would always play a role in shaping international relations. One could not hope that they could be mastered or erased; only that greater knowledge, deeper contact, and closer study would better ground them in reality and make them less fantastical. Again and again the book links feelings and judgments. International relations, Iriye explained, "are not rational developments" but derive from many causes, rational and emotional. "The human mind must always intervene between the world and a given policy." 9

This linkage is very much in keeping with current views about the nature of the human mind. The booming interest in emotion research-in psychology, anthropology, political science, history, and other fields-is fraught with controversies over defining emotions, discerning how emotional and cognitive elements interact and where one begins and the other ends, and whether emotions are universal or culturally specific. Yet a consensus has emerged that reason and emotion are not antithetical forces. Neurologists and psychologists now argue that emotions are not visceral, irrational forces, which strong-minded individuals can sublimate or repress through the exertion of willpower, but rather are essential to all processes of perception and decision-making. Cognition and emotion are separate only in our representations of mental states, not in actual mental processes, which always and necessarily integrate the two. Like the longstanding Western 


\section{PROOF}

dichotomization of body and mind, the rational/emotional pairing is an inaccurate guide to understanding human behavior. Indeed in 1997 two cognitive psychologists suggested a new term for mental processes: "cogmotion," to represent "the interactive and inseparable nature of cognition and emotion." 10

International historians are slowly taking up the challenges of studying emotion. As yet only a tiny handful, notably Frank Costigliola and Jessica Gienow-Hecht-both strongly influenced by Iriye's cultural approach-have attended explicitly to the role of emotions in foreign relations. ${ }^{11}$ Costigliola's work on the politics of the Grand Alliance at the end of World War II and the early Cold War demonstrates that personal relationships among leaders had dramatic consequences in shaping the relationships among their countrieshelping to start the Cold War, as his subtitle puts it. Though focusing on the emotionally based behaviors and dispositions of Franklin Roosevelt, Joseph Stalin, Winston Churchill, Harry Truman, and their top advisers, Costigliola is also attuned to larger cultural patterns that conditioned the expression and perception of emotions. Gienow-Hecht's study of 19th- and early 20th-century musical diplomacy argues that Germany's informal musical ambassadors in the United States created an emotional affinity between the two countries that survived World War II. Even as we attend to these exciting new lines of research, however, it is worth revisiting Iriye's classic study of "inner" relations for its insights into how to study the interactions of emotions and cognition as constitutive elements of mutual images and as causal factors in international relations.

One of the book's important conclusions is that emotional residues from the past often combine with intellectual judgments to exert a powerful influence on contemporary understandings. New situations arise, but the legacies of prior emotional states color how people understand their world. In the second half of the 19th century, for example, American observers felt a sense of gratification and approbation at Japan's Westernizing efforts. Japanese students and professionals visited the United States to study educational, agricultural, and industrial practices, and there was considerable interest in Japan in aspects of U.S. political and economic life. But, as Iriye notes, Japanese leaders wanted to adopt the methods that underpinned Western technological and military power, not to inculcate Western values. When Japan began to show tangible results from its modernizing efforts, Americans became uneasy, wondering how the West would maintain its supremacy if Asia succeeded in Westernizing. The uneasiness points to a cognitive-emotional dynamic: an awakening East could unsettle the international system and pose threats to Western security and economic interests, but the sense of threat was underpinned by ideological factors such as racism and a belief in the superiority of "Christian civilization" and by emotions such as fear of losing status. The sense of hope that had accompanied American observations of early Japanese modernization exacerbated the sense of disappointment 


\section{PROOF}

\section{Barbara Keys}

when that program turned in threatening directions. ${ }^{12}$ The concept of emotional residues, in Iriye's account, also helps explain the relative ease of the Sino-American rapprochement of the 1970s. It was not that the deep-seated feelings of hostility in place until then had been entirely superficial; rather, the shift of the 1970s was facilitated by both sides' ability to draw on older images and rhetoric of friendship predating 1949. ${ }^{13}$

Like Costigliola's study of the Grand Alliance, Iriye's account suggests that paying respect and showing deference-or failing to do so-carry great weight in international relations. As the United States and Japan both emerged as colonial powers in the Pacific beginning in the 1880s, Americans began to grow alarmed at Japanese behavior. The Russo-Japanese War of 1904-05 inflamed tensions. Iriye cites the example of Willard Straight, a longtime observer of U.S.-East Asian relations and U.S. vice consul in Korea toward the end of the war. Initially only mildly concerned about countering Japanese influence, Straight became incensed by what he perceived to be Japanese arrogance over their successes in the war. Having long been the underdogs, the Japanese were now full of swagger, Straight observed. "They're going to show us a thing or two if it can be done. They hate us. God knows the feeling is mutual." He wrote to a friend, "For no particular reason, with no real cause for complaint I now find myself hating the Japanese more than anything else in the world. It is due I presume to the constant strain of having to be polite and to seek favors from a yellow people. We cannot know them or understand them and they dislike us thoroughly." 14 Racism-like all ideologies, a construct charged with emotion-was part of the reason for Straight's extreme reaction, as was a sense of indignation at Japan's heavy-handed treatment of Korea as they imposed a protectorate. But the sense of deep antagonism Straight expressed was also an emotional reaction to growing Japanese power. The Japanese had once seemed deferential, respectful, and friendly toward Americans. Straight was angry and resentful when that deference turned to arrogance and dislike.

Asian immigration to the United States raised similar issues. The RussoJapanese War stoked in California feelings like the ones Straight experienced. Until the war, efforts at arousing mass emotion against Asian immigration had not succeeded. Fear triggered by Japan's new might changed the environment, and now such appeals struck a chord. A feeling that the West was on the defensive against a rising Asia fueled near-panic over the "yellow peril."15 President Theodore Roosevelt's contrasting response was attuned to the dangers of emotionalism. Roosevelt believed that welcoming Japan into the international system as a "civilized" power would make the country less militaristic and more peaceful. He worried that anti-Asian sentiment on the West Coast would insult Japanese feelings and trigger animosity. Courtesy and friendliness, in contrast, would forestall malice. ${ }^{16}$ As Roosevelt recognized, intangibles with deep emotional repercussions, such as the showing of respect, could have tangible consequences for international relations. 


\section{PROOF}

Meanwhile, the Chinese felt a sense of bitterness and betrayal at the 1904 passage of a bill excluding Chinese immigration from American territories. Some Chinese observers argued that the Chinese immigrants who had helped build American railways and who had labored in American factories were owed gratitude and respect for materially assisting American economic growth. Chinese merchants angered at the apparent betrayal responded with a boycott of American goods and services. ${ }^{17}$

Iriye's research also uncovered a pattern whereby American feelings for China and Japan oscillated in tandem. Favorable American emotions toward one country seemed tied to unfavorable emotions toward the other. Japan's early modernizing efforts in the late 19th century, for example, led to unfavorable contrasts with Chinese traditionalism. Yet when Japan's modernization turned the country into a potential threat, American attitudes shifted. Friendly sentiment toward China grew almost in direct proportion to rising hostility toward Japan. ${ }^{18}$ "There was a psychological need," Iriye writes, "to believe that China would not be another Japan, that it would somehow modernize itself without posing the same threat as Japan seemed to represent." The ensuing half-century of Sino-American friendship, lasting until the Chinese Revolution, derived from an American desire to help China against Japan-but, Iriye argues, the feeling was based on false premises and misunderstandings. ${ }^{19}$ In this respect, too, past emotional states influenced perceptions of current events, as, for example, Americans watching China's "awakening" in the early 20th century mentally mapped China into the position once occupied by Japan. Hopes that had been placed on Japan were now transferred to China. Because Japan was the greatest obstacle to Chinese nationalism, antagonism toward Japan flowed from the new American interest in China. Willard Straight, for one, translated his antiJapanese sentiments into whole-hearted advocacy of closer ties to China and assistance in Chinese industrialization. ${ }^{20}$

Morality, too, can be cited as an example of "cogmotion" in Iriye's account. Iriye recognized that the moral considerations that often inflected U.S. policy from about 1900 had powerful emotional components. Americans identified emotionally with China's predicament as it sought to build national power in a hostile environment. Straight's 1907 comments to a friend highlight the emotionalism of moralism: "Ours is the opportunity to befriend China in this her time of need and to aid her in straightening out her affairs here." In the early 20th century Americans saw China as an underdog, and Japan's aggressive policies seemed an affront to American notions of fair play. According to Iriye, other nations might regard Japan merely as another power, but President William Taft, by contrast, enunciated a moral policy. Americans saw it as their mission, Iriye writes, to help the victims of Japanese imperialism. ${ }^{21}$

During World War I, Woodrow Wilson's message of national self-determination resonated with the Chinese, creating an image that persisted through 


\section{PROOF}

\section{Barbara Keys}

the 1930s of America as China's "special friend." American sympathy toward China, which developed in part from sympathy for what seen as its underdog status and valiant efforts to withstand bullying, was not matched by a consensus that significant American interests were at stake. (Some of this sympathy was also instrumental, coupled as it was with arguments for naval expansion. ${ }^{22}$ ) Such feelings played a role in leading the United States and Japan into an unnecessary war. American moralism meant that U.S. leaders condemned Japanese acts, such as the invasion of Manchuria in 1931, without taking specific measures, such as fortifying bases in the Pacific that might have served as a deterrent. As Iriye puts it, in the 1930s President Franklin Roosevelt was distressed that Japan did not conform to Western principles of good behavior. Yet the administration's assessment that it was only economic and not security interests that were at stake meant that such feelings could not overcome a fear of military involvement. When rhetoric was not matched by action, Japanese leaders concluded that Americans might speak idealistically but would maintain an essentially passive policy. Combined with underestimations of America's social fiber, these perceptions lined the path to Pearl Harbor. Meanwhile the Chinese, feeling helpless and desperate, had a "psychological need" (a phrase that appears often in the book) to believe that their friend, the United States, would not stand by as Japan dismembered their country. Fear of Japan and attachment to the image of a friendly America led many Chinese to overstate U.S.-Japanese antagonism and to cling to hope of American intervention. The disappointment at actual U.S. behavior was thus all the more bitter-even, at times, hysterical. ${ }^{23}$

Emotionally inflected stories about the past, in Iriye's account, also shaped international politics. Historical memory, not as an authentic rendering of the past but as a kind of morality tale, colored U.S.-East Asian relations after World War II. Iriye implies that the widespread view that the United States and Japan went to war over China-a false view, he shows-took hold because it offered an emotionally satisfying story to all sides. This historical distortion had effects on how the public and policymakers viewed contemporary events. He argues that because Americans believed that the United States had gone to war to rescue China, they interpreted China's "ingratitude" - represented most starkly in the Chinese Communist Revolution of 1949 - as especially reprehensible. ${ }^{24}$

Intertwined with its emphasis on emotion is the book's attention to friendship as a construct in international relations. The word friendship and its variants (amity, friendliness, friends, friendly) rank among the most commonly used terms in the book. Its prominence is a reflection of the ways that diplomats, politicians, and the public in the United States, China, and Japan imbued foreign relations with anthropomorphic qualities. The rhetoric of friendship was employed frequently on all sides, producing images of relationships that created affective dispositions, expectations, and obligations that might be entirely unaligned with genuine mutual interests. 


\section{PROOF}

Yet expressions of friendship could also enhance mutual understanding by building the empathy that is necessary for each side to see the other's point of view. ${ }^{25}$

What Iriye's account reveals is an international political system in which logic plays but a small role and the reactions of leaders and publics combine elements of reasoned assessment with perceptions deeply rooted in emotions. In Across the Pacific, "psychological needs" ensured that too often observers saw what they wanted to see-namely, the sorts of behaviors and motives that assuaged their emotional states. ${ }^{26}$ Much of Iriye's indictment of mutual misperceptions is not purely emotional; cognitive biases of the sort that are now fashionable for psychologists to study also come into play. Many of the actors Iriye describes implicitly take cognitive shortcuts, rely on stereotypes, and use information closest at hand to reach judgments at odds with the facts. ${ }^{27}$ But to today's reader, attuned to the "emotional turn" in history, the explicit attention to emotion is what stands out. What one sees in Iriye's renderings are that standards of individual behavior were routinely applied to international relations: selfishness in others is considered a vice; friendliness, a virtue. Publics and policymakers expect friendly behavior to elicit gratitude; respect to elicit compliance; moral exhortation to improve behavior. The world of international relations swirls with emotion.

Looking back on Across the Pacific after the passage of nearly half a century, it is impossible not to be struck by its extraordinary sweep and multiarchival depth, its bridging of culture and power, and its prefiguring of so many of today's trends in international history. The study of nongovernmental organizations and nonstate actors has boomed in recent years, as historians have tried to come to grips with the explosion in numbers and influence of such groups since the 1970s. Across the Pacific is filled with accounts of traders, missionaries, intellectuals, and students, and their interactions with government officials. Likewise, the importance of perception and misperception, historical memory, the role of ideology, and the rise of human rights-topics that became fashionable in international history only in the decades after 1967-all receive due attention in Iriye's pathbreaking book. As international historians turn their attention to emotion, it is worth remembering that in this case, too, Akira Iriye was there first.

\section{Notes}

1. Akira Iriye, "Foreword to the Revised Edition," Across the Pacific: An Inner History of American-East Asian Relations, revised edition Chicago: Imprint Publications, 1992, p. v.

2. Akira Iriye, "Culture and International History," in Explaining the History of American Foreign Relations. New York: Cambridge University Press, 1991, pp. 215-16.

3. Akira Iriye, Cultural Internationalism and World Order. Baltimore, MD: Johns Hopkins University Press, 1997, pp. 180-1. 


\section{PROOF}

220 Barbara Keys

4. Iriye, Across the Pacific, pp. xvi, 390, 329.

5. Ibid., p. 14.

6. Ibid., p. 102.

7. Ibid., pp. 281,325 .

8. The dynamic is reminiscent of the then-predominant view among scholars of medieval and early modern Europe, which held that modernization was in part a process of subordinating unruly emotions to rationality, a consensus that was being challenged as Iriye was writing. Barbara H. Rosenwein, "Worrying about Emotions in History," American Historical Review 107 (2002): 834-6.

9. Iriye, Across the Pacific, pp. 57, 326.

10. Quoted in William M. Reddy, The Navigation of Feeling: A Framework for the History of Emotions. New York: Cambridge University Press, 2001) pp. 13-15.

11. Frank Costigliola, Roosevelt's Lost Alliances: How Personal Politics Helped Start the Cold War. Princeton, NJ: Princeton University Press, 2012; Jessica C.E. GienowHecht, Sound Diplomacy: Music and Emotions in Transatlantic Relations, 1850-1920. Chicago: University of Chicago Press, 2009. See also Alessandro Brogi, A Question of Self-Esteem: The United States and the Cold War Choices in France and Italy, 1944-1958. Westport, CT: Praeger, 2002, and Barbara Keys, "Henry Kissinger: The Emotional Statesman," Diplomatic History 35 (2011): 587-609.

12. Iriye, Across the Pacific, pp. 45-6, 60, 325-6.

13. Ibid., p. 358.

14. Quoted in ibid., pp. 103-4.

15. Ibid., pp. 104-6.

16. Ibid., pp. 106-7.

17. Ibid., pp. 93-4.

18. See, e.g., ibid., pp. 83, 118, 141.

19. Ibid., pp. 127, 112

20. Ibid., pp. 119-21.

21. Ibid., p. 124.

22. Ibid., pp. 135-7.

23. Ibid., pp. 177-81, 193, 199.

24. Ibid., p. 202.

25. See, e.g., Richard Ned Lebow, "Reason, Emotion and Cooperation," International Politics 42 (2005): 283-313.

26. See, e.g., Iriye, Across the Pacific, p. 219.

27. On cognitive biases, see, for example, Daniel Kahneman, Thinking, Fast and Slow. New York: Farrar, Straus, Giroux, 2011. 


\section{- PROOF}

Query Form

\begin{tabular}{|c|c|c|}
\hline \multirow{2}{*}{$\begin{array}{l}\text { Book Title: } \\
\text { Chapter No: }\end{array}$} & \multicolumn{2}{|l|}{ JohnsonAPA } \\
\hline & \multicolumn{2}{|l|}{ Chapter 19} \\
\hline & \multicolumn{2}{|c|}{ Queries and / or remarks } \\
\hline \multirow[t]{2}{*}{ Query No. } & Query / remark & Response \\
\hline & No Query & \\
\hline
\end{tabular}




\section{University Library}

\section{- M M I N E R VA A gateway to Melbourne's research publications}

Minerva Access is the Institutional Repository of The University of Melbourne

Author/s:

KEYS, BJ

Title:

Emotions in Intercultural Relations

Date:

2014-10-22

Citation:

KEYS, B. J. (2014). Emotions in Intercultural Relations. Johnson, RD (Ed.). Asia Pacific in the Age of Globalization, Asia Pacific in the Age of Globalization, (1), pp.212-220. Palgrave Macmillan.

Persistent Link:

http://hdl.handle.net/11343/43135 